\title{
LA INVESTIGACIÓN ACCIÓN PARTICIPATIVA
}

EN PROCESOS DE DESARROLLO COMUNITARIO: UNA EXPERIENCIA DE COOPERACIÓN INTERUNIVERSITARIA EN EL BARRIO DE JESÚS MARÍA, LA HABANA VIEJA (CUBA)'

\author{
PARTICIPATORY ACTION RESEARCH IN \\ COMMUNITY DEVELOPMENT PROCESSES: AN INTER UNIVERSITY COOPE- \\ RATION IN THE JESUS MARÍA NEIGHBORHOOD IN CUBA'S OLD HAVANA
}

\author{
A PESQUISA PARTICIPATIVA AÇÃO NO \\ PROCESSO DE DESENVOLVIMENTO DA COMUNIDADE: UMA EXPERIÊN- \\ CIA DE COOPERAÇÃO INTERUNIVERSITARIA NO DISTRITO DE JESUS \\ MARIA VELHO HAVANA (CUBA)
}

\author{
Noelia Melero Aguilar \\ UNIVERSIDAD DE SEVILLA, ESPAÑA \\ Reina Fleitas Ruíz \\ UnIVERSIDAD DE LA HABANA, CUBA
}

\begin{abstract}
RESUMEN: La experiencia que presentamos forma parte de un Proyecto de Cooperación Interuniversitario que tiene como objetivo promover un proceso de sensibilización, concienciación y participación comunitaria en torno a la problemática del agua en el barrio de Jesús María del Municipio de La Habana Vieja, Cuba. Partiendo de un enfoque crítico, emancipador y transformador de la realidad se lleva a cabo una investigación-acción-participativa que cuenta con varias fases en las que se desarrollan diferentes procesos de acción-reflexión, en los que participan investigadores, actores locales y vecinos del barrio, en la identificación de los problemas de acceso y gestión del agua, y en la elaboración de propuestas y acciones de mejora en torno a este recurso natural. La realización de la investigación visibiliza, por un lado, el enorme potencial del territorio en la producción de conocimiento, y en la vinculación de éste con la acción social. $Y$ por otro, el papel de las universidades en el fortalecimiento de las estructuras locales y comunitarias, desde la puesta en común de conocimientos interdisciplinares y metodologías de trabajo que permiten obtener soluciones integrales y acordes a las necesidades de sus beneficiarios.
\end{abstract}

PALABRAS CLAVES: Participación, Universidad, Comunidad, Investigación-Acción, Género. 
ABSTRACT: This paper presents part of an inter-university cooperation project which aims to create a process of awareness and community participation concerning the issue of water in the Jesus Maria neighborhood in the municipality of Cuba's Old Havana. Based on a critical, emancipatory and transforming approach of reality we conducted participatory action research - which has several stages which develops different processes such as action-reflection, involving researchers, neighbors and neighborhood representatives, in the identification of access problems and water management, and in the preparation of proposals and improvement actions regarding this natural resource. On the one hand the research shows, the enormous potential of the territory in the production of knowledge, and linking it to social action, and secondly, the role of universities in strengthening local community structures, from sharing interdisciplinary knowledge and work methodologies that will enable us to obtain integral solutions according to the needs of its beneficiaries.

KEYWORDS: Participation, University, community, action research, gender.

RESUMO: A experiência que apresentamos forma parte de um Projeto de Cooperação Interuniversitaria que tem como objetivo promover um processo de sensibilização, conscientização e participação da Comunidade em torno da problemática da água no bairro de Jesus Maria da Cidade antiga de Havana, Cuba. Desde um enfoque crítico, emancipado e transformador da realidade, se realizará uma pesquisa-ação-participativa com várias fases nas quais se desenvolverão diferentes processos de ação-reflexão. Nestes processos participam conjuntamente pesquisadores, atores locais e vizinhos do bairro na identificação dos problemas de acesso e administração da água, e também na preparação de propostas e ações de melhora em torno desse recurso natural.

A relação da pesquisa visualiza por um lado, o enorme potencial do território na produção de conhecimento e na vinculação deste com a ação social, e por outro lado, o papel das Universidades no fortalicimento das estruturas locais e comunitárias, colocando em comúm os conhecimentos interdisciplinar e metodologias de trabalho que permitem obter soluções globais e conformes com as necessidades de seus beneficiarios.

PALAVRAS CHAVES: Participação, Universidade, Comunidade, Pesquisa-ação, Gênero. 


\section{Introducción}

Desde el ámbito de la investigación, a mediados de los sesenta, comienza un periodo de reformulaciones y planteamientos en el que surgen nuevas propuestas metodológicas de intervención social, que apuestan por promover procesos participativos que incluyen a las personas como sujetos activos capaces de pensar por sí mismos y de ser generadores de transformación de su entorno. Partiendo de estas premisas, empezaron a surgir distintas concepciones que hacían referencia a la educación popular o al desarrollo comunitario desde donde se impulsaban procesos que permitían conocer y priorizar las necesidades de una comunidad o territorio, instando a la participación consciente y organizada de la población, que se convertía además, en protagonista activa de los programas, proyectos o intervenciones que se llevaban a cabo (Moreno, 2013). El desarrollo comunitario se asumía como proceso tendiente a fortalecer la participación y organización de la población, en la búsqueda de respuestas propias para mejorar su localidad, bajo los principios de cooperatividad, ayuda mutua y colectividad (Macías, 2013). Y donde la acción comunitaria se convertía en estrategia de transformación social que implicaba procesos de carácter educativo en la participación, el dialogo y la interacción para el desarrollo de objetivos compartidos, de modo que todo emprendimiento comunitario se caracterizara por la responsabilidad de las personas y por el fomento de un sentimiento de pertenencia que asegurara el éxito y bienestar de todos ( $V$ argas, Varela \& Aparicio, 2014)

Todos estos aspectos y premisas que conforman el desarrollo comunitario confluyen en la gestación e inicios de la Investigación Acción Participativa que surge (De Miguel, 1993; Park, 1992; Ander-Egg, 1990; Demo, 1984) como una forma de otorgar poder a la gente para que pueda asumir acciones eficaces hacia el mejoramiento de sus condiciones de vida, tomando como novedoso de este proceso, no el simple hecho de que la gente se cuestione sus condiciones y busque mejores medios de actuar para su bienestar y el de su comunidad, sino el hecho de llamar a este proceso investigación, de involucrarse en el mismo, y de conducirlo como una actividad intelectual que produce conocimientos colectivos.

\section{Introduction}

In the field of research, a new period of reformulation and propositions of new methodologies for social intervention began in the mid-sixties. They aimed at promoting participative processes that would turn people into active participants who can think for themselves and change their surroundings. In this regard, there were several conceptions regarding popular education or community development, which offered processes that allowed us to learn about and prioritize the needs of a community or a territory as well as encourage conscious and organized participation of all citizens, who actually turned into active protagonists of programs, projects or talks (Moreno, 2013). Community development was thought of as a process to strengthen people's participation and organization in order to find their own solutions and improve their community through cooperation, mutual help and collectivity (Macias, 2013). And where community action turned into a social transformation strategy that required educational processes in participation, communication and interaction for the development of shared objectives, so that every community venture is characterized by people's responsibility and sense of belonging that assures success and everyone's wellbeing (Vargas, Varela \& Aparicio, 2014).

All these aspects and propositions that make up community development unite in the gestation and beginnings of Participatory Action Research (De Miguel, 1993; Park, 1992; Ander-Egg, 1990; Demo, 1984) wich emerged as a way of giving people power so they could take on efficient action to improve their living conditions, what is revolutionary about this aspect is not only the fact that people question their conditions and look for ways to take action to improve the community's and their own wellbeing, but also the fact that they call this process research, are involved, and handle it as an intellectual activity that generates collective knowledge.

Based on the common goal of promoting, encouraging or generating active participation that fosters community development, this new line of action has always focused on including citi- 
Partiendo del objetivo común de promover, fomentar, o generar la participación activa que promueve el desarrollo comunitario, esta nueva línea de acción se centró desde sus inicios en involucrar a la población como protagonista del cambio social, combinando la acción con el conocimiento, y planteando el concepto de práctica como una postura político ideológica que permite descubrir la realidad y transformarla (Cifuentes, 2011; Lucio-Villegas, 1993; AnderEgg, 1990). La Investigación Acción Participativa se convierte así en una corriente metodológica que surge bajo el compromiso y responsabilidad de intervenir de una forma integral en el territorio donde se actúe, propiciando un modelo de dinamización territorial que proporciona el marco adecuado para que la población aborde en su territorio un proceso de reflexión y construcción de conocimiento desde la conciencia colectiva, posibilitando la autopromoción y mejora de la calidad de vida local (Basagoiti \& Bru, 2002). Un método de estudio y acción que busca "obtener resultados fiables y útiles para mejorar situaciones colectivas, basando la investigación en la participación de los propios colectivos a investigar" (Alberich, 2002, p.76).

En este sentido, la IAP otorga gran relevancia a los actores sociales, que no son considerados como simples objetos pasivos de investigación, sino que se transforman en investigadores activos que conducen una investigación con la colaboración de investigadores profesionales participando en la identificación de necesidades o problemas a investigar, en la recopilación de la información, en la toma de decisiones o en los procesos de reflexión y acción (Colmenares, 2012; Le Boterf, 1986). De este modo, se convierten en los verdaderos protagonistas de los cambios y transformaciones que se suceden en su entorno, ya que los procesos que fomentan la participación a nivel comunitario, posibilitan que los habitantes de un lugar se conviertan en sujetos sociales, que asumen un compromiso y responsabilidad por mejorar y transformar el medio en el que viven (Alberich \& Espadas, 2011; Palou, Rodríguez \& Vila, 2011).

Desde este proceso de realización conjunta y partiendo de la idea de que las personas aprendemos haciendo de forma experiencial y vivencial, donde la implicación personal tiene gran importancia, coincidimos con Caraballo (2003) en que este tipo de in- zens as the protagonists of social change by combining action with knowledge and presenting the concept of practice as an ideological political posture which allows you to discover reality and change it (Cifuentes, 2011; Lucio-Villegas, 1993; Ander-Egg, 1990). Therefore, Participatory Action Research (PAR) becomes a methodological current that emerges under the commitment and responsibility to intervene, in an integral manner, within your context by offering a territorial dynamization model which provides a suitable framework so that communities can address a process of reflection and knowledge building from collective consciousness, enabling self promotion and a better quality of life (Basagoiti \& Bru, 2002). It is a study and action method that aims "to get reliable and useful results to improve collective situations, basing research on the participation of the people who are directly involved" (Alberich, 2002, p.76).

In this regard, PRA provides citizens great relevance, so that they are not simply spectators of research, but become active researchers that conduct research with the help of professional researchers and are able to identify needs or problems that need research, collect information, participated in decision making or reflection and action processes (Colmenares, 2012; Le Boterf, 1986). As a result, they become the real protagonists of change that takes place in their surroundings, since the processes used to encourage community participation, enable inhabitants to become social citizens that take on responsibility and commitment to improve and transform the context in which they live in Alberich \& Espadas, 2011; Palou, Rodríguez \& Vila, 2011).

Based on this process of combined accomplishments and based on the idea that people learn by doing and experience, where personal implication is significantly important, we agree with Caraballo (2003) that this type of research bridges the gap between the researcher and the people being researched, turning the research into a collective learning process where new knowledge is discovered, created and recreated and where the researcher plays the role of a facilitator / mediator of collective construction

[ 206 ] NOELIA MELERO AGUILAR, REINA FLEITAS RUÍZ 
vestigación rompe con la distancia entre el investigador y el colectivo investigado, convirtiendo a la investigación en un proceso de aprendizaje colectivo donde se van descubriendo saberes y se va creando y recreando el conocimiento. Donde el investigador desarrolla el rol de facilitador/mediador de los procesos de construcción colectiva, dinamizando el entorno social a través de técnicas e instrumentos que facilitan la comunicación y la reflexión (Ramos, 2012). De esta forma, posibilita acercarnos a la realidad, e implicarnos en ella, descubriendo la necesidad de transformación directamente con la gente que percibe la situación de la problemática, la necesidad y la voluntad de transformarla. Esta implicación a la que nos referimos supone sumergirse en las vivencias, problemáticas y tiempos en los que se desarrollan las comunidades con las que se trabaja, suponiendo esto un proceso de adaptación por parte de los investigadores al ritmo y los modos de resolver y solventar las situaciones que en un momento dado se pueden plantear (Ferreira, Coimbra \& Menezes, 2012).

En este sentido, la investigación acción participativa no ofrece un listado de soluciones, sino que propicia situaciones de interacción activa, diálogo y negociación entre las personas implicadas, que tras procesos reflexivos dan soluciones a sus problemas, a partir de propuestas, que se ajustan a la realidad, en la medida en que han sido participadas a partir de las confianzas mutuas generadas en el proceso (Diez, 2013; Rodríguez Villasante, Montañez \& Martí, 2002). Un proceso, en el que se pretende descubrir la realidad, analizarla y transformarla y que conlleva una serie de pasos, que desde la investigación-acción se han determinado como espiral de ciclos, en los que confluyen planificación, acción, observación, sistematización y reflexión, para posteriormente volver a la planificación, nuevo paso a la acción, y así sucesivamente (Tekin \& Kotaman, 2013). Como ejemplo de las distintas fases que se llevan a cabo en los procesos de Investigación Acción e Investigación Acción Participativa, son varios los autores que han venido realizando clasificaciones que pueden servir como referentes. En este sentido, Lewin (1973) los denomina ciclos de acción reflexiva y los divide en planificación, acción y evaluación. Kemmis (1988) nos acerca a cuatro fases o momentos como son planificación, acción, observación y reflexión. Por otro lado, Pérez (1998) se refiere a pasos o etapas: processes by stimulating the social environment through techniques and means that facilitate communication and reflection (Ramos, 2012).This means we are able to come close to reality and get involved by identifying the need to change directly from the people who perceive the problematic situation, the need and are willing to change it. This implication means we will get involved with experiences, problems and moments of the communities we work with, meaning the researchers will have to adjust to the rhythm and ways of settling and solving situations that may occur (Ferreira, Coimbra \& Menezes, 2012).

In this regard, participatory action research does not provide a list of solutions, it actually provides situations of active interaction, dialogue and negotiation between the persons who are involved. Through reflection processes they find solutions to their problems, and give proposals that fit reality, to the extent that they have been shared based on the trust generated during the process (Diez, 2013; Rodríguez Villasante, Montañez \& Martí, 2002). It is a process that intends to discover reality, analyze and transform it; the process has several steps that have been identified from action research, such as spiral models, which join with: planning, action, observation, systematization and reflection, and then go back to planning, new step to action, and so on (Tekin \& Kotaman, 2013). As an example of several phases that take place in the Action Research and Participatory Action Research processes, there are various authors who have done classifications which may be used as benchmarks. In this regard, Lewin (1973) calls them action reflection cycles and divides them into planning, action and evaluation. Kemmis (1988) presents four phases or moments, planning, action, observation and reflection. On the other hand, Pérez (1998) refers to steps or stages: diagnosis, building the Action Plan, implementing the action plan and the observations, reflection and interpreting results, and back to planning again if necessary. Finally, we look at the scheme presented by Marti (2002), which takes us closer to a proposal of phases in this type of research, where the author emphasizes that although the design of these phases such as its duration vary 
diagnóstico, construcción del Plan de Acción, la ejecución del plan de acción y su observación, la reflexión e interpretación de resultados y vuelta a la replanificación si fuera necesario. Finalmente hacemos referencia al esquema que sigue Martí (2002) que nos acerca a una propuesta de fases en este tipo de investigaciones, donde el autor puntualiza que, aunque el diseño de estas fases, como su duración, variarán en función de cada contexto, si se pueden centrar unos ejes estratégicos que servirán como esqueleto de IAP.

Tabla ı. Fases y Técnicas de la IAP

Etapa de pre-investigación: Síntomas, demanda y elaboración del proyecto

o. Detección de unos síntomas y realización de una demanda (desde alguna institución, generalmente administración local) de intervención.

1. Planteamiento de la investigación (negociación y delimitación de la demanda, elaboración del proyecto)

\section{Primera etapa. Diagnóstico}

Conocimiento contextual del territorio y acercamiento a la problemática a partir de la documentación existente y de entrevistas a representantes institucionales y asociativos.

2. Recogida de información.

3. Constitución de la Comisión de Seguimiento.

4. Constitución del Grupo del IAP.

5. Introducción de elementos analizadores.

6. Inicio del trabajo de campo (entrevistas individuales a representantes institucionales y asociativos).

7. Entrega y discusión del primer informe.

\section{Segunda etapa. Programación}

Proceso de apertura a todos los conocimientos y puntos de vista existentes, utilizando métodos cualitativos y participativos.

8. Trabajo de campo.

9. Análisis de textos y discursos.

10. Entrega y discusión del segundo informe.

11. Realización de talleres.

Tercera etapa. Conclusiones y propuestas

Negociación y elaboración de propuestas concretas.

12. Construcción del Programa de Acción Integral (PAI).

13. Elaboración y entrega del informe final.

Etapa post-investigación: Puesta en práctica del PAI y evaluación. Nuevos síntomas.

Alberich, 2002 according to each context, it is possible to utilize strategic elements that may be used as the frame of PAR.

Based on these theoretical assumptions, the aim of Participatory Action Research is to become a strong means used to transform social and local reality by turning local actors in communities into protagonists. Participatory methodologies become promoters of processes that generate significant changes in the management and organization of territories, from the enga-

Table 1. Stages and techniques of PA

The pre research stage: Symptoms, demand and making the project

o. Detect some symptoms and make an intervention demand (from some institution, generally local administration).

1. Approach towards the research (negotiation and delimitation of the demand, making the project).

\section{First stage.Diagnosis}

Contextual knowledge of the territory and access to the problem from the existing documentation and interviews to institutional representatives.

2. Collect information.

3. Establish a monitoring commission.

4. Establish the PAR group.

5. Introduce analyzing elements.

6. The start of fieldwork (personal interviews to institutional and association representatives).

7. Present and discuss the first report.

\section{Second stage. Programming}

Discuss all points of view and knowledge through qualitative and participative methods.

8. Field work.

9. Book analysis and discussion.

10. Present and discuss the second report.

11. Workshops.

Third stage.Conclusions and proposals

Negotiating and making concrete proposals.

12. Develop the Integral Action Program (IAP) or

Programa de Acción Integral (PAl, in Spanish).

13. Present the final report.

Post research stage: Implement the Integral Action Programand evaluation. New symptoms

[ 208 ] NOELIA MELERO AGUILAR, REINA FLEITAS RUÍZ 
Desde estos postulados teóricos, la finalidad de la investigación acción participativa es convertirse en un instrumento con un fuerte potencial transformador de la realidad social y local, desde el protagonismo de los diferentes actores locales que conforman la comunidad. Donde las metodologías participativas se constituyen en impulsoras de procesos que generan cambios significativos en la gestión y organización de los territorios, desde la implicación de sus beneficiarios, en acciones más equitativas y sustentables.

\section{Desarrollo de la Investigación}

En este marco que venimos describiendo se configura nuestro proyecto de investigación, que surge desde el compromiso establecido por investigadores de la Universidad de Sevilla y de la Cátedra UNESCO de Desarrollo Humano y Sostenible de la Universidad de La Habana, en la realización de proyectos e investigaciones participativas, intercambio de metodologías y buenas prácticas a nivel comunitario. De esta forma, a partir de la demanda realizada por uno de los barrios de la Habana Vieja, donde los problemas de acceso y gestión del agua se convierten en una de las prioridades que se vienen trabajando a nivel comunitario, se empieza a gestar la posibilidad de trabajar en torno a esta cuestión, a través de una investigación acción participativa que aborde la problemática identificada, desde un proceso en espiral en el que confluyan la reflexión y la acción, involucrando a los diferentes actores del barrio desde el diagnóstico, hasta las propuestas de mejora que se lleven a cabo.

\subsection{Contexto}

El marco en el que se desarrolla la investigación nos sitúa en La Habana Vieja, un municipio que se caracteriza por promover procesos de participación social desde las estructuras y los poderes locales y donde cobra gran protagonismo el trabajo comunitario, impulsando programas e iniciativas que responden a los intereses básicos comunes de la población, posibilitando soluciones colectivas a los problemas que se plantean en la cotidianidad. Y donde la comunidad y el barrio, se convierten en la entidad sociocultural básica, desde la que se pro- gement of its beneficiaries in more equal and sustainable actions.

\section{Research development}

The framework we have been describing configures our research project, which emerges from the commitment made by researchers from Universidad de Sevilla and Cátedra UNESCO de DesarrolloHumano y Sostenible from Universidad de La Habana to conduct participatory research and projects, exchange methodologies and good practice in communities. In this regard, based on the request made by one of the neighborhoods in Habana Vieja, where the problems of water management and access to water are one of the priorities being worked on in the community, we had the idea of working on this issue through a participatory action research that addresses the problem from a spiral model, where reflection and action converge, and involves people in the neighborhood in the diagnosis as well as in the improvement suggestions that will take place.

\subsection{Context}

Research takes place in Old Havana where municipality is known for fostering social participation from its structures and local authorities and where community service plays an important role by launching programs that respond to people's basic common interests which enables there to be collective solutions to daily problems and where the community and the neighborhood become the basic sociocultural entity from where social, economic, political and cultural interactions are produced. 
ducen las interacciones sociales, económicas, políticas y culturales.

En este sentido, uno de los barrios que forman parte de este municipio y que responde a las características que describimos es el barrio de Jesús María situado en el extrarradio del centro histórico, con una fuerte impronta social y cultural, y con serias dificultades socio habitables como el deterioro y hacinamiento en la viviendas, ya que la gran mayoría siguen siendo ciudadelas, con habitáculos pequeños y baños compartidos, además de los problemas que lo acusan en relación al abastecimiento de aguas, salideros y desechos sólidos, y las defectuosas condiciones de las redes técnicas de acueducto y alcantarillado, que impiden un adecuado bienestar de la población. Todas estas características se suman al alto nivel de población desempleada y a los graves problemas sociales que les afectan, convirtiéndose en una de las zonas prioritarias y de especial atención, para el gobierno local, que trata de impulsar iniciativas de carácter social que den una respuesta a las necesidades y deficiencias que caracterizan al barrio y al municipio en general.

Una de estas iniciativas comunitarias, y donde se gesta la propuesta de nuestra investigación, es el Taller de Transformación Integral de Barrio de Jesús María ${ }^{2}$, un espacio que tiene como objetivo promover el desarrollo comunitario, a partir de la participación activa y consciente de la población y las diversas entidades y organizaciones de base del barrio. Y desde donde se participa en la realización de planeamientos participativos en el que los vecinos identifican los problemas y necesidades, fortalezas y potencialidades con los que cuenta el barrio y donde se identificó como una de las prioridades, abordar la problemática de acceso, uso y gestión del agua (Melero, 2012).

\subsection{Objetivos}

Objetivo general:

Promover un proceso de sensibilización, concienciación y participación comunitaria en torno al acceso, uso y gestión del agua, en el barrio de Jesús María, del Municipio de la Habana Vieja, Cuba.
In this regard, one of the neighborhoods that is part of this municipality and responds to the abovementioned characteristics is the Jesús María neighborhood. The neighborhood, located in the outskirts of the historic center, with a strong social and cultural mark, and with serious socio habitable difficulties like deterioration and overpopulation in housing. Most of these place are still neighborhoods with small rooms and shared bathrooms, including problems regarding water supply, leaks, solid waste and faulty conditions of water and sewage networks, which hinder adequate living conditions. All these characteristics add up to a high level of unemployed people and serious social problems that they are affected by, turning this place into a priority that requires special attention from the local government which seeks to promote social initiatives to respond to the needs and deficiencies of the neighborhoods and the municipality in general.

One of these community initiatives, and where our research proposal is generated, is the Integral Transformation Workshop in the Jesús María neighborhood ${ }^{6}$, whose aim it is to promote community development from the active and conscious participation of the population and the different entities and organizations in the neighborhood. Neighbors participate in participatory plannings and identify problems, needs, strengths and potential of the neighborhood in the Integral Transformation Workshop; one of the identified priorities was to address the problem of access, used and management of water (Melero, 2012).

\subsection{Objectives}

General objective:

Promote a process of community awareness and participation regarding the access, use and management of water in the Jesús María neighborhood in the municipality of Old Havana, Cuba.

[ 210 ] NOELIA MELERO AGUILAR, REINA FLEITAS RUÍZ 
Objetivos específicos:

- Implicar a los vecinos del barrio de Jesús María, en la construcción colectiva de soluciones relacionadas con el acceso, uso y gestión del agua.

- Fortalecer la capacidad de los actores locales del barrio de Jesús María, dotándoles de conocimientos técnicos de gestión de agua y saneamiento, contribuyendo a su sostenibilidad.

- Promover una cultura del uso del agua donde la responsabilidad social y ambiental de los actores locales del barrio de Jesús María, sean pilares para hacer un buen uso del agua como bien común.

\subsection{Metodología}

Para llevar a cabo este proceso de sensibilización, concienciación y participación comunitaria en torno a la temática del agua, se plantea utilizar una metodología participativa, desarrollando una investigación-acción participativa que permitiera construir este proceso desde la realización de diferentes fases y etapas que ya se describieron anteriormente, siguiendo el modelo de Alberich (2002). Las técnicas de recolección de información utilizadas fueron: entrevistas en profundidad, observación participante, análisis de testimonios, grupos de discusión y reflexión (Alberich, Sotomayor \& Amezcua, 2014; Rojas, 2010; Albert, 2007; Taylor \& Bogdan, 2000). Los instrumentos utilizados fueron diario del investigador, diario de campo para los observadores participantes, registros descriptivos, registros de grupos de discusión y de autorreflexión (Quintana, 2006). La información recolectada se analizó siguiendo el proceso de categorización distintivo de los estudios cualitativos, para lo cual se recurrió a la codificación, categorización y la triangulación, siguiendo la propuesta de Miles, Huberman \& Saldana (2014). Identificándose categorías que permitieron la conformación de aproximaciones teóricas que se presentan en el desarrollo del artículo.
Specific objectives:

- Get everyone in the Jesus Maria neighborhood involved in the collective construction of solutions to the access, use and management of water.

- Strengthen the capability of the people in the Jesus Maria neighborhood by providing them with technical knowledge of water management and sanitation, which will contribute to its sustainability.

- Promote a culture of water use where social and environmental responsibility plays a significant role in using water appropriately for common good.

\subsection{Methodology}

To carry out this process of community awareness and participation regarding the water issue, we suggest using a participatory methodology by carrying out a participatory action research that will allow us to build this process with the different stages we described before by using the Alberich model (2002). The techniques used to collect information were: in depth interviews, participant observation, analysis of testimony, discussion groups and reflection (Alberich, Sotomayor \& Amezcua, 2014; Rojas, 2010; Albert, 2007; Taylor \& Bogdan, 2000). The instruments we used were: the researcher's diary, the field diary for the observers, descriptive records, the discussion group and the self-reflection records (Quintana, 2006). The information we collected was analyzed using the distinctive categorization process of qualitative studies, therefore we turned to coding, categorization and triangulation by using the proposal of Miles, Huberman \& Saldana (2014). We identified categories that allowed the formation of theoretical approaches that are presented throughout the article. 
Tabla 2. Técnicas e instrumentos de recogida y análisis de la información

\begin{tabular}{|l|l|l|}
\hline Metodología & \multicolumn{1}{|c|}{ Técnicas } & \multicolumn{1}{|c|}{ Instrumentos } \\
\hline Cualitativa & $\begin{array}{l}\text {-Cartografía So- } \\
\text { cial } \\
\text {-Observación } \\
\text { Participante } \\
\text {-Entrevistas en } \\
\text { profundidad } \\
\text {-Grupos de dis- } \\
\text { cusión } \\
\text {-Matriz DAFO } \\
\text { (Debilidades, } \\
\text { Amenazas, For- } \\
\text { talezas y Opor- }\end{array}$ & $\begin{array}{l}\text { - } \\
\text {-Diario del investi- } \\
\text { gador } \\
\text {-Diario de los ob- } \\
\text { servadores partici- } \\
\text { pantes }\end{array}$ \\
tunidades) & $\begin{array}{l}\text {-Registros descrip- } \\
\text { tivos } \\
\text {-Registros de gru- } \\
\text { pos de discusión } \\
\text {-Registros de auto- } \\
\text { rreflexión }\end{array}$ \\
\hline
\end{tabular}

Elaboración propia.

\subsection{Muestra}

En relación a la muestra se trató que fuera lo más representativa posible, contando por un lado, con todos los grupos poblacionales: hombres, mujeres, adolescentes y niños, y por otro, con una representación de las principales organizaciones barriales; delegados del Consejo Popular y representantes del Comité de Defensa de la Revolución (CDR); Técnicos del Taller de Transformación Integral de Barrio; Representantes de Instituciones: Federación de Mujeres Cubanas (FMC), médico de familia, técnicos de cultura, deporte y educación; Representantes de proyectos sociales: la Casa del Niño y la Niña; la Ludoteca Pinocho; el Centro Cultural Unión Fraternal; el Circulo Infantil Pescadores y la Escuela Primaria Quintín Banderas. Además de contar con una muestra significativa de vecinos. En este sentido, participaron las familias de la circunscripción $4 \mathrm{O}^{3}$, por ser una de las que mayor problemática recoge en lo que se refiere al acceso y mantenimiento del agua para su uso doméstico.

\subsection{Fases de la Investigación-Acción-Participativa}

La realización de nuestro trabajo de investigación se concretó en cinco fases que reflejamos de forma esquemática en la tabla que presentamos a continuación, basándonos en la propuesta de fases y téc-
Table 2. Techniques and tools for collecting and analyzing information

\begin{tabular}{|c|c|c|}
\hline Methodology & Techniques & Tools \\
\hline Qualitative & $\begin{array}{l}\text {-Social carto- } \\
\text { graphy } \\
\text {-Participant ob- } \\
\text { servation } \\
\text {-Interviews } \\
\text { Cross } \\
\text {-Groups Discus- } \\
\text { sion } \\
\text {-Matriz SWOT } \\
\text { (Weaknesses, } \\
\text { Threats, } \\
\text { Strengths and } \\
\text { Opportunities) }\end{array}$ & $\begin{array}{l}\text {-Social mapping } \\
\text { - Journal of resear- } \\
\text { cher } \\
\text { - Journal Of partici- } \\
\text { pant observers } \\
\text {-Records descrip- } \\
\text { tive } \\
\text {-Records Discus- } \\
\text { sion groups } \\
\text {-Records Self-re- } \\
\text { flection }\end{array}$ \\
\hline
\end{tabular}

Compilation.

\subsection{Sample}

We intended the samples to be as representative as possible; therefore we worked with all the population groups: men, women, adolescents, children, as well as representatives from the main neighborhood organizations, representatives from the local government and representatives from the Committee for the Defense of the Revolution (CDR); technicians from the neighborhood Integral Transformation Workshop; representatives from the following institutions: Federation of Cuban Women (FMC), family doctor; culture, sports and education specialists; Representatives of social projects: Boys' and Girls' house; Pinocchio's toy library; The fraternal union cultural center; The pescadores Children's circle and the Quintín Banderas Primary school. Additionally, samples were also collected from a significant number of neighbors. In this regard, the participating families were from circunscripción $40^{7}$ since it has one of the biggest problems regarding access and maintenance of water for domestic use.

\section{5.- The Participatory Action Research Stages}

Our research project was done in five stages that are schematically shown in the following table, based on the PAR stages and techniques proposed by Alberich (2002) which we talked about

[ 212 ] NOELIA MELERO AGUILAR, REINA FLEITAS RUÍZ 
nicas de IAP de Alberich (2002) que comentamos anteriormente. En el modelo que presentamos, se describen los distintos pasos que se siguieron, reflejando como los procesos de acción y reflexión se integraron de manera permanente durante toda la investigación.

Tabla 3. Fases de la Investigación-Acción Participativa

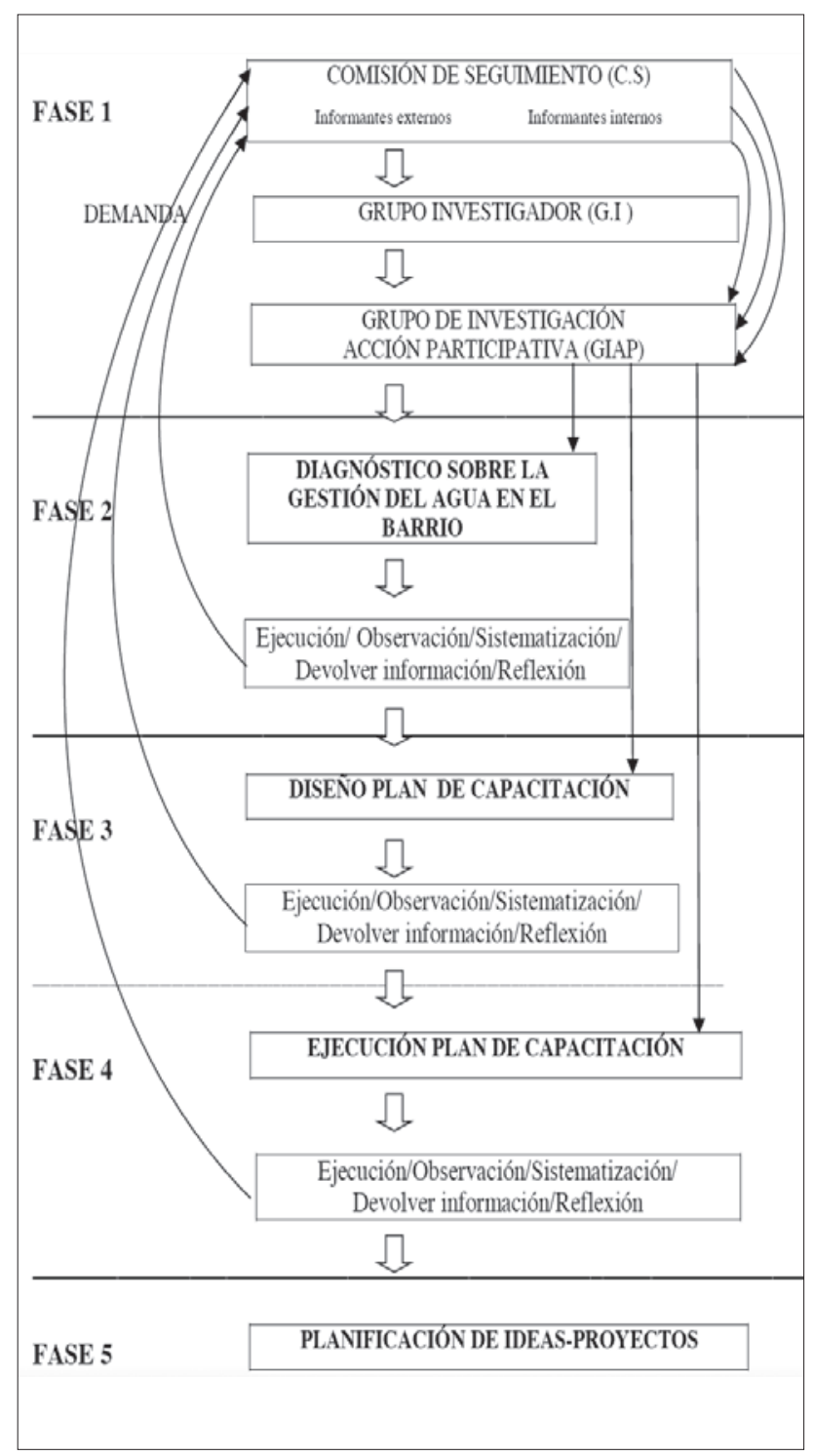

Elaboración propia.

La primera fase consistió en realizar un proceso de observación, contacto e intercambio en el barrio de Jesús María, lo que nos permitió concretar la demanda que se realizaba en torno a la cual giraría la investigación. De esta forma, se planteó una primera sistematización del proyecto que se llevaría a cabo, respondiendo a tres cuestiones claves; ¿Para quién y para que se hace?; ¿quién lo hace? y ¿ipor qué, cómo y cuándo? earlier. The model we presented describes the different steps we followed, reflecting the way the action and the reflection processes were integrated permanently during all the research.

Table 3. Stages of Participatory Action Research

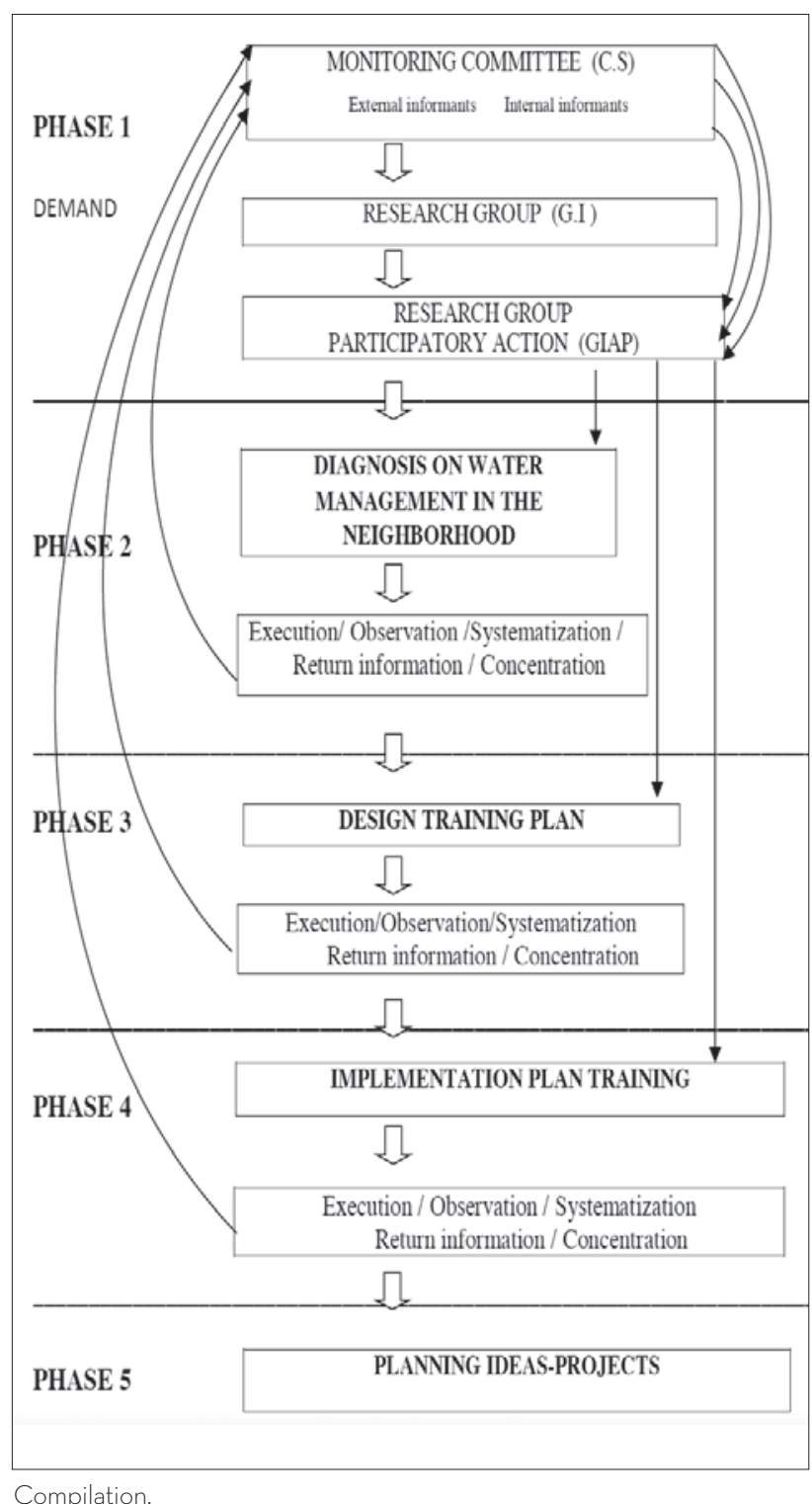

The first stage was to conduct a process of observation, contact and exchange in the Jesus Maria neighborhood which allowed us to identify the demand that was taking place, our research will be conducted according to that demand. Hence, the first systematization of the project was presented, answering three key questions: Who is this for and why is it being done? Who is doing it? Why? How? And When? 
Tabla 4. Pautas previas para el diseño del Proyecto de Investigación

\begin{tabular}{|ll|}
\hline $\begin{array}{l}\text { ¿Para quién y para } \\
\text { que se hace? }\end{array}$ & $\begin{array}{l}\text { Justificación y efectos } \\
\text { que tendrá en la } \\
\text { comunidad }\end{array}$ \\
\hline ¿Quién lo hace? & $\begin{array}{l}\text { Constitución del/los } \\
\text { equipo/os investigador }\end{array}$ \\
\hline ¿Por qué, cómo & Objetivos/ \\
y cuándo? & Metodología/Fases/ \\
& Temporalización \\
\hline
\end{tabular}

Martí, 2002.

Como ya mencionamos anteriormente, la demanda inicial que sustenta nuestra investigación gira en torno a los problemas de acceso, manejo y gestión del agua en el barrio de Jesús María y cómo influyen estas cuestiones en sus habitantes. Partiendo de esta tesis se inicia un proceso de auto reflexión con la comunidad que nos lleva a plantearnos la necesidad de abordar esta problemática de una forma más integrada, abriendo un proceso de reflexión, diálogo e intercambio que permita a los miembros de la comunidad comprender como en torno a este recurso se despliegan una serie de prácticas sociales de las cuales emergen diferenciadas identidades culturales y de género. Entendiendo así que los problemas que surgen con respecto al agua en el barrio, deben ser abordados considerando el entramado de relaciones sociales que en torno a ellos se articulan. Este será por tanto, el argumento que justifica la necesidad de abordar estas cuestiones desde una metodología que promueva el dialogo permanente entre diversos saberes, experiencias y prácticas, y lo que nos lleva a plantear el proceso a través de una investigación, acción, participativa.

Posteriormente, se llevó a cabo la constitución de los diferentes grupos que formaron parte de la investigación. Por un lado, el Grupo Investigador (GI) que estaría compuesto por dos investigadoras, de ambas universidades, que se encargaron de promover e impulsar el proceso participativo. Por otro lado, se reunió a los responsables/representantes de vecinos, del Taller de Transformación Integral de
Table 4. Pre Guidelines for Design Research Project

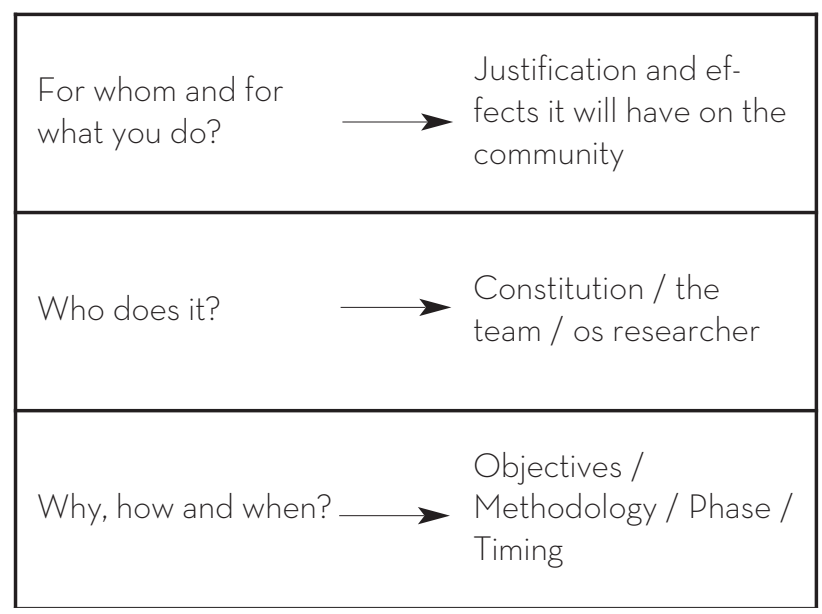

Martí, 2002.

As mentioned earlier, the demand or the request that underpins our research revolves around the problems of access to and management of water in the Jesus Maria neighborhood and how these problems influence inhabitants. In this regard, we started a process of self-reflection with the community which took us to approach this problem with a more integral manner, opening a process of reflection, dialogue and interchange that would allow the community members to understand how based on this resource there are a series of social practices from which different cultural and gender identities emerge. We understand that the problems regarding water in the neighborhood should be addressed considering the social fabric. Therefore, this is the argument that justifies the need to address these issues from a methodology that promotes permanent dialogue between several insights, experiences and practices, which leads us to consider the process through participatory action research.

Subsequently, we formed different groups that were part of the research. On the one hand, the Research Group (GI) made up by two researchers, from two universities, who were in charge of promoting and encouraging the participatory process. And on the other hand, representatives from the neighborhood, the integral transformation workshop and the local government; we also created the monitoring committee responsible for advising, accompanying and

[ 214 ] NOELIA MELERO AGUILAR, REINA FLEITAS RUÍZ 
Barrio, y del Consejo Popular, y se conformó la Comisión de Seguimiento que se encargaría de asesorar, acompañar y evaluar el proceso. Finalmente, el grupo investigador, promueve la conformación del Grupo de Investigación Acción Participativa (GIAP) compuesto por investigadores de ambas universidades y técnicos del Taller de Transformación Integral de Barrio que tendrá la tarea de realizar la investigación apoyándose en el grupo investigador, con el compromiso de devolver toda la información que elabore a la Comisión de seguimiento para posteriormente, recibir la retroalimentación de los informantes internos y externos, y continuar con el proceso participativo.

Como último paso de esta primera fase, y siguiendo las pautas de Martí (2002), se diseña un primer borrador de lo que sería el proyecto de investigación.

Tabla 5. Apartados del proyecto de investigación

\begin{tabular}{|l|}
\hline 7. Demanda inicial y justificación de la investigación \\
\hline 2. Objetivos generales de la investigación \\
\hline 3. Fases a seguir y técnicas que se utilizarán \\
\hline 4. Cronograma /temporalización fases \\
\hline
\end{tabular}

Martí, 2002.

En la segunda fase de la Investigación, desde el GIAP se llevó a cabo un amplio Diagnóstico participativo que nos permitió conocer a fondo la problemática que giraba en torno al acceso, gestión y saneamiento del agua en el barrio, y como afectaban las diferentes problemáticas identificadas, a la población. Para la realización del diagnóstico se llevó a cabo una primera recogida de información general sobre cómo se contextualiza el agua como recurso en el territorio de la Habana Vieja, recurriendo a diversas fuentes como la bibliografía existente, estudios recientes sobre la calidad de agua en el municipio recabando datos de la Oficina Municipal de Estadísticas (OME) y realizando entrevistas a expertos/as y técnicos/as, lo que nos permitió determinar elementos analizadores claves para el estudio. Paralelamente a estas actividades se fue realizando el diseño de la investigación y de los instrumentos y técnicas que se utilizarían. evaluating the process was also created. Finally, the research group, encouraged the creation of the Participatory Action Research Group (GIAP) made up by researchers from both universities and technicians from the neighborhood Integral Transformation Workshop whose task is to conduct research by relying on the research group, with the commitment to return all the information it puts together to the monitoring commission so that then we can get feedback from the internal and external informants, and continue with the participatory process. The last step of this first stage, and following Marti's (2002) guidelines, is to design the first draft of the research project.

Tabla 5. Apartados del proyecto de investigación

7. Initial Demand and justification of research

2. General objectives of the research

3. Steps to follow and techniques to be used

4. Schedule / timing phase

Martí, 2002

In the second stage of the research, the GIAP carried out an in depth participatory analysis that enabled us to have a thorough understanding of the problem regarding the access to, management and sanitation of water in the neighborhood, and how they affected the inhabitants. To carry out the diagnosis, we first collected overall information on how water is contextualized as a resource in the Old Havana territory by using several sources such as existing bibliography, recent studies on water quality from the municipality's statistics office (OME, in Spanish), and interviews to specialists and technicians; these helped us determine key analyzing elements for the study. Concurrently, we did the research design and identified the means and the techniques that will be used. 
Tabla 6. Técnicas utilizadas en el Diagnóstico

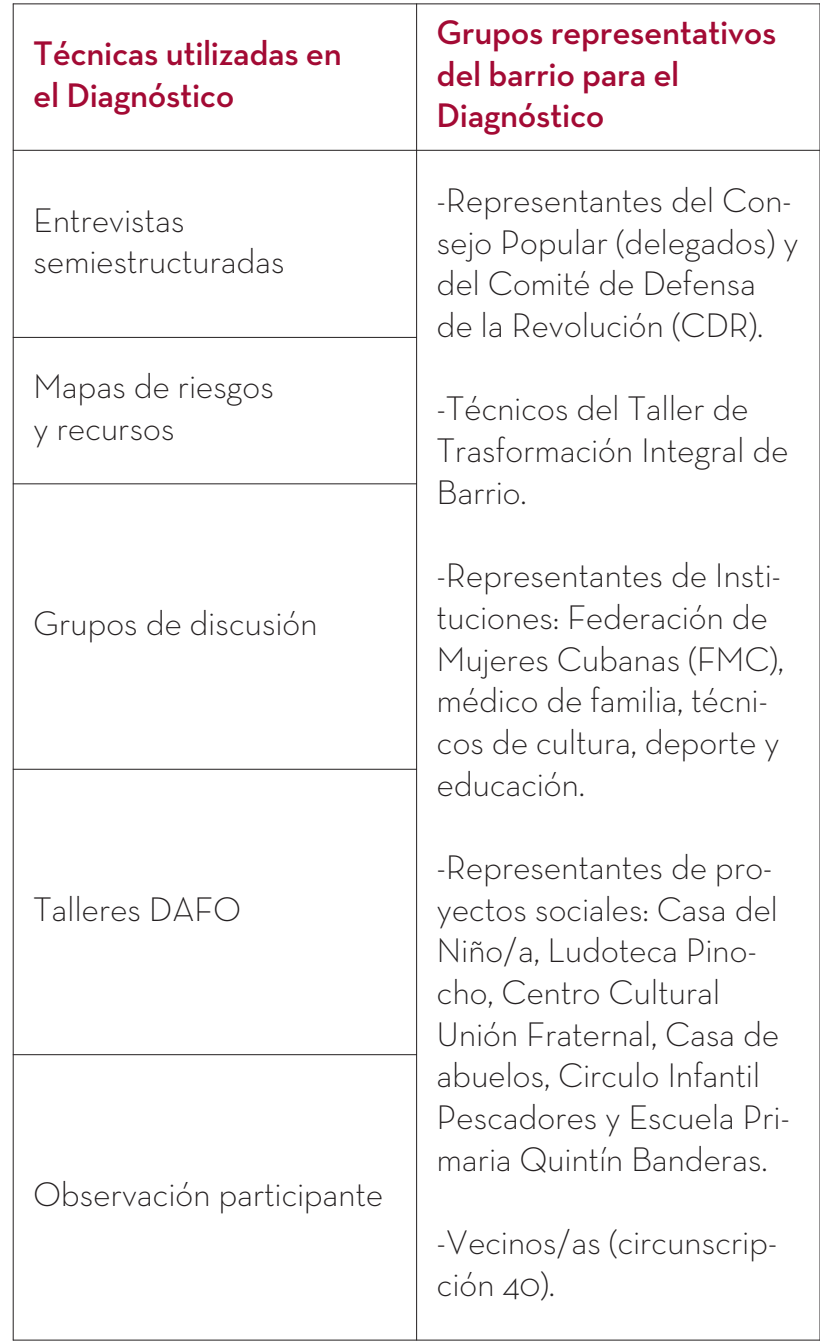

Elaboración Propia.

En cuanto al trabajo de campo, se comenzó por realizar entrevistas semiestructuradas a delegados del Consejo Popular, al personal técnico del Taller de Trasformación Integral de Barrio, a representantes de proyectos sociales, y a los vecinos/as. En concreto se realizaron diez entrevistas que fueron grabadas y transcritas a través del programa de análisis cualitativo Atlas.ti. La realización de las entrevistas nos permitió obtener información sobre cómo afecta la problemática del agua en el territorio, desde diferentes percepciones, identificando discursos, propuestas y estrategias. Otra de las técnicas que se utilizaron para la realización del diagnóstico fue la cartografía social, a través de los Mapas de Riesgos y Recursos. Esta técnica, basada en la participación comunitaria, se convierte según Coipel (2003) en un instrumento eficaz de evaluación de necesidades en un contexto o territorio, con el objetivo de
Table 6. Techniques Used in the Diagnosis

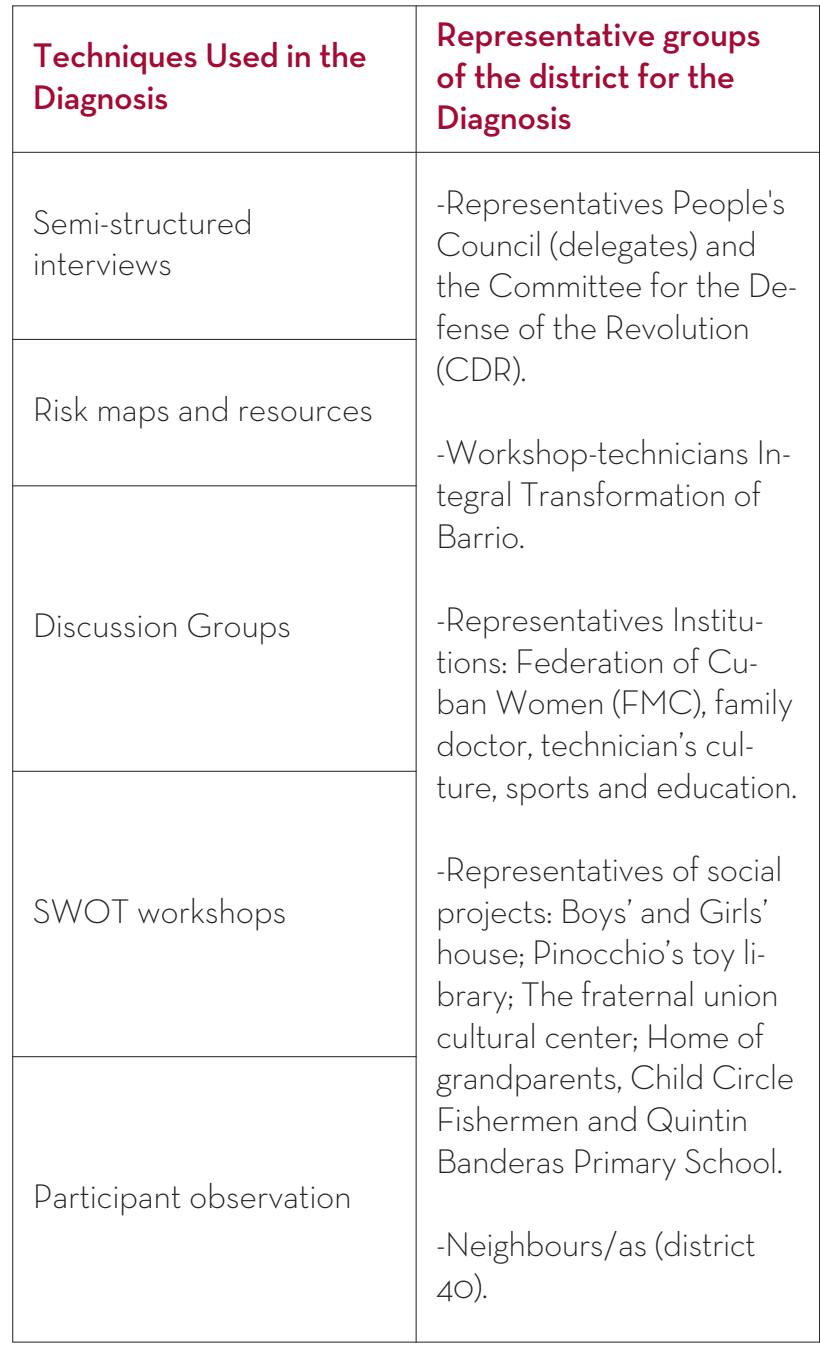

Compilation.

Regarding the field work, we started with semi structural interviews to representatives from the local government, the technical staff of the neighborhood integral transformation workshop, representatives of social projects, and neighbors. In all, ten interviews were recorded and transcribed with the qualitative data analysis and the Atlas.ti research software. The interviews gave us information about how the water problem affects the territory from different perspectives, by identifying speeches, proposals and strategies. Another technique used for the diagnosis was social mapping, risk and resource maps. According to Coipel (2003), this technique, based on community participation, is an efficient tool to evaluate the needs within a context or territory in order to come up with solutions to the previously identified problems in communities.

[ 216 ] NOELIA MELERO AGUILAR, REINA FLEITAS RUÍZ 
ofrecer solución a problemáticas previamente identificadas en las comunidades. De esta forma, se diseñaron cuatro mapas de riesgos y recursos, en los que se ubicaron iconos que representaron los problemas existentes en el territorio relacionados con el agua, asociando la relación entre los problemas, su concentración y los recursos potenciales con los que contaba el barrio para solucionarlos. La cartografía social que es una técnica simple de aplicar y de fácil comunicación, facilitó la identificación y análisis de la información de forma inmediata y colectiva, lo que nos permitió trabajar de manera integral los aspectos físicos, ambientales y sociales identificados.

Toda esta información recogida se complementó con la realización de Talleres donde se trabajó la técnica DAFO. Una herramienta participativa que a través de la lluvia de ideas, facilitó definir y contextualizar la problemática del agua en el barrio, desde los aspectos negativos o "de riesgo" analizando las debilidades y amenazas, así como desde aquellos que se consideran positivos o "de éxito" a través de las fortalezas y oportunidades. Se realizaron cuatro talleres que permitieron a los participantes intercambiar y debatir en torno a estas cuestiones, involucrando a las autoridades locales, en el debate y en el establecimiento de prioridades.

Con el objetivo de generar un mayor proceso de autorreflexión y diálogo entre los integrantes que representaban a la comunidad, en el desarrollo de la investigación, otra de las técnicas que se utilizaron fue la realización de grupos de discusión. De esta forma, se conformaron cinco grupos de discusión lo que nos permitió conocer la visión de los participantes desde sus posiciones sociales y de representatividad de las entidades e instituciones a las que pertenecían, contrastando varias posiciones discursivas. Finalmente, hacemos referencia a la observación participante que como señala Martí (2002) se convierte en un elemento indispensable que debe estar de manera transversal y continuada a lo largo de la IAP. Por lo que esta técnica acompañó todo el proceso de investigación llevado a cabo, a partir de una serie de indicadores que se tomaron como referencia, en todas las actividades que se observaron. Tanto la información de los grupos de discusión, como de la observación participante, se recopiló, transcribió, y analizó a través un sistema
In this regard, four risk and resource maps were designed considering the relation between the problems, its concentration and the neighborhood's potential resources to solve the problems. The existing problems regarding water in the territory were marked with symbols. Social mapping is a simple technique to apply and of easy communication, it made the identification and analysis of the information easy, which allowed us to work integrally on physical, environmental and social aspects.

The collected information was complemented by workshops where they used the SWOT technique was used; the technique is a participatory tool that made it easier to define and contextualize the water problem in the neighborhood through brainstorming the negative or "risky" aspects, the weaknesses or threats, as well as the positive or "successful" aspects, strengths and opportunities. Four workshops were held so that participants, the local authorities, could exchange and debate these issues, and establish priorities. In order to generate a better process of self reflection and dialogue among community representatives during the research, we used the discussion groups technique. We formed five discussion groups that allowed us to learn the participants' points of view from their own social and institutional positions. Finally, we refer to the participant observation, and as Marti (2002) points out it becomes an essential element that should be used throughout the PAR. This technique accompanied the entire research process from a series of indicators that were used as reference in all the observed activities. Both the information from the discussion groups and the participant observation was compiled, transcribed, and analyzed through a system of coded categories, and together with the compiled information from other analyzed instruments, they turned into a final document of conclusions.

In accordance with the PAR procedure, we returned the documents with the diagnosis results to the monitoring commission and to the citizens, who were involved, through workshops. In this regard, all the information that was co- 
de categorías codificadas, que junto con la información recopilada por los otros instrumentos analizados, se volcó en un documento final de conclusiones.

Siguiendo el procedimiento de la IAP, el documento con los resultados del diagnóstico, se devolvió a la Comisión de Seguimiento, pero también a la población implicada a través de la realización de talleres. De manera que todas las aportaciones realizadas fueron devueltas al GIAP que las adaptó al documento elaborado para poner en marcha el siguiente paso. Cabe destacar, esta parte de la investigación como una de las más enriquecedoras, al potenciar la discusión sobre "productos concretos" que son generados del trabajo realizado con la participación de todos/as, lo que se conforma como una oportunidad para poder corregir errores y modificaciones si fuera necesario, durante el resto del proceso.

La tercera fase de nuestra investigación se centró en la realización de un plan de acción que contemplara diferentes programas de capacitación. Esta propuesta formativa se convierte en el resultado de los debates realizados en la Comisión de seguimiento y en las asambleas, al diagnóstico que se llevó a cabo en el barrio, donde la necesidad de recibir una formación teórico-práctica sobre uso y gestión del agua, y sobre las relaciones de género en el acceso y la gestión de este recurso, se constituyen como las principales demandas realizadas por todos los grupos participantes en el proyecto de investigación. En este sentido, se trabajó en el diseño de los programas de capacitación, en los que participaron investigadores de ambas universidades y miembros del GIAP, elaborando un material-dossier con los contenidos de ambos cursos, contemplando desde una aproximación a los principales conceptos teóricos, hasta material didáctico con técnicas y dinámicas para trabajar de manera participativa el abordaje de la temática. Por otro lado, también se realizaron trípticos para divulgar las capacitaciones que contemplaban; temas, cronograma de trabajo, docentes responsables, etc... Finalmente, una vez elaborados los materiales y trípticos con la programación, se devolvieron a la comisión de seguimiento que junto con el GIAP realizaron sugerencias, y aportaciones que fueron incluidas en el material, para continuar con el siguiente paso de la Investigación.

En la cuarta fase, se realizaron las capacitacio- llected was returned to the GIAP (Participatory Action Research Group) and they then adapted them to the document in order to continue with the next step. It should be noted that this part of the research was one of the most enriching, since it enhanced the discussion on "particular products" which are made with everyone's participation and which turns out to be an opportunity to correct any mistakes if necessary, during the rest of the process.

The third stage of our research focused on developing an action plan that includes different training programs. This proposal is the result of the discussions held with the monitoring commission and the assemblies on the neighborhood, where the need for theoretical and practical training on the use and management of water, and on gender relations in the access and management of this resource, constitutes the main demand made by all the groups participating in the research project. On this subject, we worked on the design of the training programs with the participation of researchers from both universities and GIAP members. We created a dossier material with contents from both courses, considering key theoretical concepts, and didactic material with techniques and dynamics to work on the issues in a participatory manner. On the other hand, there were also leaflets with information regarding the training programs, the topics, schedules, professors, and so on.

Finally, once the material and the leaflets were done, we returned them to the monitoring commission who along with GIAP made suggestions that were then included in the material in order to continue with the next step in the research. The training programs were held in the fourth stage and they were aimed at all the people involved in the research: local government representatives, social initiative professionals and neighbors, the contents were adapted to their particular needs and demands. Training for key community figures is one of the priorities and permanent actions in the action plan, since it guarantees the quality and efficiency of management and of the people involved in the process of community service (Góngora, Labrada \& Columbié, 2008). After the training sessions,

[ 218 ] NOELIA MELERO AGUILAR, REINA FLEITAS RUÍZ 
nes, que estuvieron orientadas a los diferentes grupos/actores participantes en la investigación; delegados de gobierno local, técnicos/as de iniciativas sociales y vecinos/as, adaptando los contenidos a sus necesidades y demandas concretas. Ya que la capacitación a las figuras claves de la comunidad constituye una de las acciones priorizadas y permanentes del plan acción ya que ello garantiza la calidad y efectividad de la dirección y de los implicados en el proceso de trabajo comunitario (Góngora, Labrada \& Columbié, 2008). Al finalizar las capacitaciones se realizaron talleres de evaluación en los que se pusieron en común los logros y avances obtenidos en el proceso formativo, concretándose algunas propuestas de proyectos y acciones de mejora, que surgieron como resultado de las capacitaciones llevadas a cabo. Estas propuestas de ideas-proyecto fueron debatidas con la Comisión de seguimiento y el GIAP, pero no llegaron a profundizarse, quedando plasmadas en una quinta fase, que no llegó a implementarse.

\section{Resultados de la Investigación}

En cuanto a la primera fase se constituyeron los diferentes grupos que formaron parte de la investigación (comisión de seguimiento, grupo investigador y grupo de investigación acción participativa) consiguiendo así implicar a una amplia representación de diferentes actores locales del barrio, comprometiéndolos a reflexionar, dialogar e intercambiar con los grupos a los que representaban, las distintas propuestas o acciones que se llevaron a cabo durante todo el proceso de investigación. Garantizando así una amplia representación y participación a nivel técnico, institucional y ciudadana. La IAP en este sentido ha supuesto abrir un espacio de reflexión cooperativa, de discusión, de indagación, y de descubrimiento de los participantes que ha posibilitado dinamizar y comprometerse provocando conscientemente un cambio emancipador como así lo señalan otras investigaciones (Bergold \& Thomas, 2012; Sepulveda, Calderón \& Torres, 2012).

En cuanto a la segunda fase los resultados del diagnóstico visibilizaron;

- Los graves problemas con los que cuenta el barrio en relación al deterioro de las redes de alcantarillado y acueducto, la calidad del agua, su workshops were held to evaluate the achievements and advances of the training program. The workshops provided some project proposals and improvement actions that were later discussed with the monitoring commission and GIAP. However, the proposals and the improvement actions were not discussed any deeper and were taken to a fifth stage which was not implemented.

\section{Research Results}

As for the first stage, different groups which were part of the research were created (the monitoring commission, the research group and the participatory action research group) so as to include several different representatives from the neighborhood and get them to reflect, talk and share the proposals or actions that were carried out throughout the research. This guaranteed a vast representation and participation at the technical, institutional and civic level. The PAR has opened a space for cooperative reflection, discussion, inquiry, and discovery which has enabled participants to make a commitment to emancipating change as expressed in other research (Bergold \& Thomas, 2012; Sepulveda, Calderón \& Torres, 2012).

Regarding the second stage, the diagnosis results showed:

- The serious problems the neighborhood faces in the deterioration of sewerage and aqueduct, water quality, irregular water supply, and leaks in the streets, houses and buildings due to years of poor maintenance. 
suministro irregular, y la existencia de salideros en las calles, casas y edificios debido a un mantenimiento deficiente que se ha prolongado durante años.

- La dificultad de acceso a este recurso, ya que hay zonas del barrio donde el agua no llega y debe proveerse a través de pipas, ${ }^{4}$ a lo que se une la sequía que padece Cuba que ha incidido significativamente en los bajos niveles de agua con los que cuenta el acueducto de Albear que es el que suministra a la zona.

- Los serios problemas con el almacenamiento de agua, ya que no toda la población dispone de tanques en las azoteas de las viviendas y se ven obligados a improvisar distintas formas de acopiar este recurso como el uso de cubos y otros recipientes.

- La falta de sensibilización sobre el uso responsable del agua que consumen; falta de conocimiento sobre los procesos de desinfección, y como abordar los problemas de salud que acusan a la población.

- El impacto sobre las mujeres que provoca esta situación, porque además del importante papel que desempeñan en cargar el agua son las que llevan el peso de las tareas domésticas, fundamentales en la reproducción de la vida cotidiana. Las percepciones sobre la repercusión de los problemas en el acceso al agua reflejaron esta realidad desigual de la distribución del trabajo doméstico. Y aunque la gran mayoría reconocía que ese problema tiene impacto para mujeres y hombres, existe una mayor incidencia sobre las mujeres (Melero, 2011; Ramírez, 2007).

Por otra parte, los instrumentos y técnicas que se utilizaron durante el desarrollo del diagnóstico (entrevistas, grupos de discusión, talleres, mapeo social) como así lo señalan algunos autores propiciaron la reflexión, el diálogo y la toma de conciencia sobre los problemas que les afectaban (McAllan, 2015; Sallah, 2014). En este sentido, la IAP promueve la conexión entre la reflexión y la acción como proceso continúo donde los participantes aprenden de sus propias experiencias, lo que les permite tomar la propiedad del cambio (Wilson, Ho \& Walsh, 2007).

En cuanto a la tercera fase se propició la participación e implicación de los actores del barrio en
- Difficulties to access to this resource, as there are areas in the neighborhood where there is no water and it is supplied through pipes, ${ }^{8}$ additionally Cuba suffers from a drought that has significantly influenced the low levels of water in the Albear aqueduct, which supplies water to the area.

- The serious water storage problems, since most of the population does not have water tanks in the rooftops of their homes. Thus, they improvise to store water in buckets or other containers.

- The lack of awareness of responsible water use; the lack of information on disinfection processes and how to deal with health problems.

- The impact this situation has on women, because besides having to carry the water they also have domestic chores to carry out, and they are fundamental for reproduction. Perceptions about the problems of access to water demonstrated the unequal distribution of housework. And although most people recognized that this problem affects both women and men, there is a greater impact on women (Melero, 2011; Ramírez, 2007).

On the other hand, as stated by some authors, the tools and the techniques used during the analysis (interviews, discussion groups, workshops, and social mapping) encouraged reflection, dialogue, and awareness of the problems they faced (McAllan, 2015; Sallah, 2014). In this regard, PAR promotes a link between reflection and action as a continuous process where participants learn from their own experiences, which allows them to take change into their own hands (Wilson, Ho \& Walsh, 2007).

In the third stage we encouraged the involvement and participation of neighborhoodrepresentatives in the proposals and solutions, which were later presented in an action plan. Some of the main ideas in the plan are to offer training sessions to make people aware of and facilitate technical knowledge, develop mobility strategies to access water, organize the cleaning and maintenance of pipes and drains for

[ 220 ] NOELIA MELERO AGUILAR, REINA FLEITAS RUÍZ 
la construcción colectiva de soluciones y propuestas que se plasmaron en un plan de acción. Entre las principales ideas que recogió este documento estaba el diseño de capacitaciones orientadas a sensibilizar y facilitar conocimiento más técnico, la elaboración de estrategias de movilización para el acceso a este recurso; la organización de la limpieza y mantenimiento de canalizaciones y desagües que permitieran un mejor uso; y pautas para diseñar ideas-proyectos que fueran financiados a nivel nacional $e$ internacional y que permitieran una solución a problemáticas concretas. A diferencia de otras aproximaciones de investigación, la meta del proceso de IAP es la transformación de la realidad social de los participantes a través del empoderamiento de éstos en la toma de decisiones. Una transformación que se logra en aproximaciones sucesivas, pasando de problemas simples a los más complejos, con base en un plan de acción (Horowitz, Robinson \& Seifer, 2009; Balcázar, 2003).

En cuanto a la cuarta fase el desarrollo de las capacitaciones posibilitó fortalecer las capacidades de los actores locales del barrio. De esta forma se consiguió sensibilizar y formar a los participantes, por un lado, sobre la necesidad de valorizar el agua como recurso natural; las malas prácticas que se ejercen en el manejo del agua; la no conveniencia de consumo de agua no potable y los riesgos que esto conlleva, por otro lado, sobre las relaciones de género en el acceso y gestión del agua y la necesidad de establecer mecanismos de resolución de conflictos de forma equitativa, y finalmente, facilitarles conocimientos más técnicos sobre la gestión de agua y el saneamiento, informando sobre sistemas domésticos de filtración y desinfección que permitieran asegurar la potabilidad del agua, y sobre nuevas formas de aprovechar y asegurar el buen uso de este recurso. En otros estudios similares donde se reconoce a la comunidad como una entidad social y cultural con participación activa de sus miembros en todas las fases de la investigación, se constata como la IAP promueve procesos de formación, de co-aprendizaje y empoderamiento de los participantes, como una oportunidad y espacio para formarse, para compartir propuestas, para poner de manifiesto las dificultades técnicas, profesionales e institucionales que permiten mejorar y transformar los contextos, con una mayor garantía de sostenibilidad de la acciones que se llevan a a better use, and guidelines to design ideas projects meant to provide solutions to specific problems and which could be financed nationally or internationally. Unlike other research methods, the aim of PAR is to transform the participant's social reality through empowerment, by giving them decision making skills. This transformation is achieved in continuous approximations, going from simple to more complex problems, based on an action plan (Horowitz, Robinson \& Seifer, 2009; Balcázar, 2003).

With reference to the fourth stage, the training sessions helped strengthen people's capabilities. Therefore, we were able to make participants aware of the importance of water as a natural resource; the misuse of water; the risks of drinking non potable water, as well as gender relations to access and manage water and the need to establish mechanisms to solve problems equally. Finally, we provided people with technical knowledge about the management of water and sanitation by notifying them about domestic disinfection systems that ensures potable water, and about ways to use this resource accordingly. In other similar studies where a community is recognized as a social and cultural entity and its people are active participants in all the stages of the research, we observed how PAR promotes education, colearning and empowerment processes for its participants as they get an opportunity to be educated and share proposals to present technical, professional and institutional difficulties that will allow us to improve and transform the contexts with greater sustainability for the actions that are taking place (López, Couret \& Guaimaro, 2014; Sepulveda, Calderón, Ruíz \& Beltrán, 2008; Israel, Schulz, Parker \& Becker, 2001). 
cabo (López, Couret \& Guaimaro, 2014; Sepulveda, Calderón, Ruíz \& Beltrán, 2008; Israel, Schulz, Parker \& Becker, 2001).

\section{Conclusiones}

Como proceso de construcción de conocimiento colectivo, la Investigación Acción Participativa ha posibilitado formar a los participantes en temáticas de tipo técnico y en capacidad de análisis local, consiguiendo que todos los actores involucrados se mantengan en constante aprendizaje y producción de conocimientos, a través de la identificación de problemas, necesidades y aspiraciones de la comunidad, buscando de manera conjunta soluciones y alternativas para mejorarlas. En este tipo de metodologías no se espera que sólo unos aprendan o que lo hagan al final, sino que todo el proceso implica una interrelación entre la acción y el pensamiento en un aprendizaje continuo (Brydon-Miller, Greenwood \& Maguire, 2003).

En tanto proceso participativo, la Investigación Acción Participativa ha generado un alto poder de implicación y articulación entre los principales actores y decisores del barrio, y la población, convocados a través de diferentes espacios, canales y ámbitos de participación. Garantizando así la representatividad, corresponsabilidad y compromiso en la investigación como principales promotores. Por otra parte, ha impulsado diferentes momentos de acción-reflexión-acción que ha permitido idear y conformar distintas propuestas orientadas a abordar, desde una perspectiva local y propia, posibles actuaciones y planes de mejora en el barrio. Generando una visión autocrítica en los participantes, lo que les ha permitido en todo momento analizar, reformular, y corregir sobre los pasos que se iban realizando (Balcazar, 2003). Permitiendo someter a análisis, crítica y discusión los resultados de las diferentes fases, diseminando la información en sus grupos de origen, de modo que una buena parte de la población participara en las sugerencias a los contenidos, resultados o conclusiones mediante talleres y jornadas de trabajo, convirtiéndose en un proceso abierto, a nuevas incorporaciones y a las opiniones del conjunto de actores del barrio.

Es interesante analizar también el impacto de los diferentes instrumentos utilizados en el desarrollo de la investigación, donde ha tenido un gran protagonismo las técnicas de comunicación como la entre-

\section{Conclusions}

As a process of building collective knowledge, Participatory Action Research has enabled us to educate participants on technical topics and local analysis, getting all the people who were involved to keep learning and producing knowledge through identifying a community's problems, needs and desires to find ways of solving or improving them. In this type of methodology, we not only want some people to learn or to do so at the end; this whole process requires an connection between action and thought in continuous learning (Brydon-Miller, Greenwood \& Maguire, 2003).

As a participatory process, Participatory Action Research has generated a lot of involvement and coordination among the main people and decision makers in the neighborhood, and the population, who were called upon through different spaces, channels and participation context, thus ensuring representativeness, co-responsibility, and commitment to research. On the other hand, it has promoted several moments of action- reflection-action that has allowed us to design and shape various proposals aimed at addressing, from a local self-perspective, possible action and improvement plans in the neighborhood. This generates a self-critical view from participants, which has allowed them to analyze, reformulate and correct anything along the way (Balcazar, 2003). Allowing the results from different stages to be analyzed and discussed by disseminating the information in their groups of origin, so that most of the population will participate in proposals regarding the contents, results or conclusions in workshops and work meetings, thus it becomes a process that is open to new participants and their opinions.

It is also interesting to analyze the impact of the means that were used in the research, such as interviews which were prominent and allowed us to collect data from different members in the community; the field observation techniques allowed us to collect information that was later analyzed through visualization techniques like the risk and resource map. The discussion groups and workshops were fundamental to work with

[ 222 ] NOELIA MELERO AGUILAR, REINA FLEITAS RUÍZ 
vista, lo que ha permitido recabar información desde diferentes puntos de vista de los miembros de la comunidad; técnicas de observación de campo que han permitido recolectar información en el terreno que posteriormente fue analizada usando técnicas de visualización como el mapa de riesgos y recursos. O técnicas que han generado dinámicas de grupos como los talleres o grupos de discusión, fundamentales para trabajar con grupos de personas y lograr una participación efectiva y armoniosa, lo que ha facilitado además, obtener y sintetizar información cualitativa del diagnóstico (Mac Donald, 2012).

La gradualidad en la aplicación y desarrollo de las fases es otro de los resultados de la Investigación Acción Participativa llevada a cabo donde la incorporación de la experiencia, conocimiento y práctica de los actores participantes ha ido incidiendo a lo largo de la Investigación de forma pautada. Estableciéndose una retroalimentación constante entre el grupo investigador y el grupo de investigación acción participativa, sobre lo que se estudiaba, diagnosticaba y se llevaba a la práctica consiguiendo cambios y mejoras desde el inicio del proceso. Lográndose de esta manera potenciar una mayor integralidad en las soluciones al generar en los principales actores del barrio la capacidad de comprender e interpretar la realidad, valorando posibles opciones para intervenir en ella.

Partiendo de la idea de Ander-Egg (2003) de que la I-A-P posibilita estudiar una realidad con el fin de resolver problemas que son significativos para un determinado grupo o colectivo que tiene el propósito o deseo de superarlos, la investigación llevada a cabo nos permite entender a través de una experiencia concreta como la Investigación Acción Participativa logra acercar a las comunidades, un método que permite movilizar y generar conciencia colectiva en torno a los problemas y necesidades que les afectan, posibilitando, a partir de sus propios recursos la planificación de acciones necesarias para transformarla.

Un proceso que combina la teoría y la práctica, generando el empoderamiento de las personas, que además se convierten en protagonistas de los cambios que se realizan en su entorno. En este sentido, es interesante resaltar el papel de las universidades, contribuyendo a apoyar estos procesos, impulsando el intercambio docente, metodológico y de buenas prácticas. $Y$ donde el potencial humano y de conocimientos que poseen, trasciende los muros univer- groups of people and achieve effective participation which also enabled us to get and synthesize the qualitative data from the diagnosis (Mac Donald, 2012).

The gradual application and development of the stages is another result of Participatory Action Research where the incorporation of the participant's experience, knowledge and practice has been an influence throughout the research. Carrying out constant feedback between the research group and the participatory action research group about the research, the diagnosis and what was being carried outenabled changes and improvements since the beginning of the process. Therefore, we managed there to be greater integration among the main people in the neighborhood to find solutions by giving them the ability to understand and interpret reality and assess several options.

Considering Ander-Egg's idea (2003) that PAR allows us to study reality in order to solve significant problems of a particular group that wishes to overcome them, the conducted research allows us to understand, through experience, how Participatory Action Research manages to get communities together, it is a method that generates collective awareness about the problems and needs that they are affected by, and enables them to use their own resources to plan suitable actions to transform them.

It is a process that combines theory and practice, and empowers people who later become protagonists of the changes that take place in their context. In this regard, it is interesting to highlight the role that universities play in supporting such processes by encouraging professor exchange programs, methodologies and good practice. Human potential and knowledge go beyond the university walls and serve to transform communities and local territories.

All these issues have converged in this experience, but additionally we faced a special disadvantage which was to work in a neighborhood with very special socioeconomic characteristics. But mainly, a neighborhood with a strong participatory mark caused by characteristics ofCuban's own reality and university support in several social initiatives in the last few years. This 
sitarios para servir de acompañamiento en la trasformación de las comunidades y territorios locales.

En la experiencia llevada a cabo han confluido todas estas cuestiones, pero además se ha contado con un especial hándicap, trabajar en un barrio con características muy particulares a nivel socioeconómico, pero sobre todo con una fuerte impronta participativa, generada por las características de la propia realidad cubana, y por el acompañamiento universitario, en las diferentes iniciativas sociales que se han ido desarrollando en él, en los últimos años. Lo que ha favorecido un gran dinamismo y rigor por parte de los actores del barrio que han participado en la Investigación, por la familiaridad con la metodología, técnicas e instrumentos utilizados.

En este marco, el compromiso de las universidades debe atender a favorecer a nivel comunitario procesos formativos de los agentes y técnicos locales de las comunidades con las que se trabaje, facilitando recursos y medios que generen una apropiación social del conocimiento (Kearney, Zuber-Skerritt \& Wood, 2013). Es importante, apoyar la realización de diagnósticos, evaluaciones y estudios de casos que permitan conocer la situación de partida antes de llevar a cabo cualquier acción de desarrollo, incidiendo en que estas investigaciones recojan en todo momento las necesidades reales de la población. Se deben impulsar fundamentalmente metodologías participativas que permitan la implicación de investigadores, técnicos, políticos y vecinos en la acción concreta, con el objetivo de que la propia gente sea motor de cambio y transformación de su propia realidad.

Fomentar el intercambio de profesionales con el objetivo de extrapolar experiencias y asimilar otras nuevas, facilitando la creación de redes y el conocimiento de lecciones aprendidas que permitan construir un pensamiento crítico con las distintas realidades con las que se comparte. Para ello es importante favorecer la transferencia de tecnologías con el objetivo de que las comunidades desarrollen sus propias capacidades de investigación, innovación o adaptación a sus necesidades locales, velando porque todas las acciones que se desarrollen fomenten el empoderamiento de las mujeres y relaciones de género más justas y equitativas. has given people in the neighborhood who participated in the research great dynamism and rigor since they are familiar with the methodology, techniques and means that were applied.

In this context, the commitment of universities should be to educate communities by providing resources and means to generate a social acquisition of knowledge (Kearney, Zuber-Skerritt \& Wood, 2013). It is important to support the realization of diagnosis, evaluations and case studies that reveal the starting point before carrying out any action, this stresses that research must collect the real needs of people at all times. Participatory methodologies that enable the participation of researchers, specialists, politicians, and neighbors in specific actions must be promoted in order for people themselves to be the driving force of transforming their own reality.

Fostering the exchange of professionals to export experiences and assimilate new ones which facilitate the creation of networks and experiences that will help to build critical thinking skills based on with the different realities we live with. Thus it is important to encourage the transfer of technology in order to help communities develop their own research and innovation skills and adapt them to local needs, ensuring that all actions that are being carried out promote the empowerment of women and fairer gender relations. 


\section{Referencias / References}

Albert, M. (2007). La Investigación Educativa. Claves Teóricas. Madrid: Mc Graw Hill.

Alberich, T. (2002). Perspectivas de la Investigación Social. In T. Rodríguez Villasante, M. Montañez, \& J. Martí (Coords.), La investigación social participativa: Construyendo ciudadanía (Vol. 1, pp. 125-142). Madrid: El Viejo Topo.

Alberich, T. (2008). IAP, Redes y Mapas Sociales: desde la investigación a la intervención social. Revista de trabajo social portularia. 8, 131-151.

Alberich, T., Sotomayor, E., \& Amezcua, T. (2014). La planificación estratégica. In T. Alberich et al., Planificación y gestión: Manual para la acción social (pp. 93-114). Madrid: Dykinson.

Alberich, T. \& Espadas, M. A. (2011). Asociacionismo, participación ciudadana y políticas locales: planteamiento teórico y una experiencia práctica en Jaén. Alternativas, 18, 119-146. doi: 10.14198/ALTERN2011.18.07

Ander-Egg, E. (1990). Repensando la investigación-acción participativa. Vitoria: Gobierno Vasco.

Ander-Egg, E. (2003). Métodos y Técnicas de Investigación Social. Buenos Aires: Lumen Hvmanitas.

Balcázar, F. (2003). Investigación acción participativa (iap): aspectos conceptuales y dificultades de implementación. Fundamentos en humanidades Universidad Nacional de San Luis, 8, 59-77.

Basagoiti, M., \& Bru, P. (2002). Mira quién habla: El trabajo con grupos en la I.A.P. En T. Rodríguez Villasante, M. Montañez, \& J. Martí (Coords.), La investigación social participativa: Construyendo ciudadanía (Vol. 1, pp. 125-142). Madrid: El Viejo Topo.

Bergold, J., \& Thomas, S. (2012). Participatory Research Methods: A Methodological Approach in Motion. Forum Qualitative Sozialforschung / Forum: Qualitative Social Research, 13 (1). Retrieved from http://nbn-resolving.de/urn:nbn:de:0114-fqs1201304.

Brydon-Miller, M., Greenwood, D., \& Maguire, P. (2003). Why action research? Action Research, 1 (1), 9-28.

Caraballo, R. (2003). Espacios educativos informales para la educación de personas adultas y el desarrollo comunitario. En E. Lucio-Villegas (Ed.), Apuntes sobre educación de personas adultas y acción comunitaria (pp. 45-46). Valencia: Diálogos.

Cifuentes, R. (2011). Diseño de proyectos de investigación cualitativa. Buenos Aires: Noveduc.

Coipel, M. (2003). El Mapa de Riesgos y Recursos en el planeamiento local con participación comunitaria. Autor.

Colmenares, A. M. (2012). Investigación acción participativa: una metodología integradora de la acción y el conocimiento. Voces y Silencios: Revista Latinoamericana de Educación, 3 (1), 102-115.

De Miguel, M. (1990). La investigación en la acción: un paradigma para el trabajo social. In R. Martín, \& G. Pérez (Eds.), Investigación en Animación Sociocultural (pp. 75-89). Madrid: UNED.

Demo, P. (1984). Investigación participante. Mito y realidad. Buenos Aires: Kapelusz.

Díez, E. J. (2013). Investigación acción participativa: el cambio cultural con la implicación de los participantes. Revista Electrónica Interuniversitaria de Formación del Profesorado, 16 (3), 115-131. doi: 10.6018/reifop.16.3.186171

Ferreira, P., Coimbra, J., \& Menezes, I. (2012). "Diversity within Diversity" - Exploring Connections between Community, Participation and Citizenship. Journal of Social Science Education, 11(3), 120-134. doi: 10.2390/jssev11-i3-96

Góngora, A., Labrada, E., \& Columbié, K. (2008). Algunas consideraciones sobre la aplicación del trabajo comunitario integrado en proyectos de animación sociocultural en Cuba. Animador Sociocultural: Revista Iberoamericana, 2 (2), 76-90.

Horowitz, C., Robinson, M., \& Seifer, S. (2009). Participatory Research From the Margin to the Mainstream Are Researchers Prepared?. Key Issues in outcomes research, 2633-2642. doi: 10.1161/CIRCULATIONAHA.107.729863

Israel, B. A., Schulz, A. J., Parker, E. A., \& Becker, A. B. (2001). Community-based Participatory Research: Policy Recommendations for Promoting a Partnership Approach in Health Research. Education for Health, 14 (2), 182-197. doi: 10.1080/13576280110051055

LA INVESTIGACIÓN ACCIÓN PARTICIPATIVA EN PROCESOS DE DESARROLLO COMUNITARIO: UNA EXPERIENCIA DE COOPERACIÓN... [ 225 ] 
Kearney, J., Zuber-Skerritt, O., \& Wood, L. (2013). Community-University Partnerships Using Participatory Action Learning and Action Research (PALAR). International Journal of Community Research and Engagement, 6, 113-130.

Kemmis, K., \& McTaggart, R. (1988). Cómo planificar la investigación-acción. Barcelona: Laertes.

Le Boterf, G. (1986). La investigación participativa: Una aproximación para el desarrollo local. En J. M. Quintana (Ed.), Investigación participativa: Educación de adultos (pp.24-36). Madrid: Narcea.

Lewin, K. (1973). Resolving Social Coflicts: Selected Papers in Group Dynamics. London: Souvenir Press.

López, G., Couret, M., \& Guaimaro, Y. (2014). Formación y capacitación en liderazgo, desarrollo personal, derechos y educación ambiental de las mujeres que habitan el Parque Nacional Archipiélago Los Roques. Anales de la Universidad Metropolitana, 14 (1), 91-110.

Lucio-Villegas, E. (1993). La investigación participativa en educación de personas adultas: La construcción de un saber colectivo. Sevilla: Kronos.

Mac Donald, C. (2012). Understanding participatory action research: a qualitative research: a qualitative research methodology option. Canadian Journal of Action Research, 13 (2), 34-50.

McAllan, L., Moore, S., Cowman, P., Kampfe, C., Sales, A., \& Smith, M. (2015). Profesional developement needs of community rehabilitation program staff: focus group research International. Journal of Disability, Community \& Rehabilitation, 4 (2). Retrieved from http://www.ijdcr.ca/VOLO4_O2_CAN/articles/mcallan.shtml

Macías Reyes, R. (Agosto 2013). Desarrollo comunitario: Procedimiento metodológico para su implementación en las comunidades. Revista Caribeña de Ciencias Sociales. Retrieved from de http://caribeña.eumed.net/desarrollo-comunitario/.

Martí, J. (2002). La investigación-acción-participativa: Estructuras y fases. In T. Rodríguez Villasante, M. Montañez, \& J. Martí (Coords.), La investigación social participativa: Construyendo ciudadanía (Vol. 1, pp. 79123). Madrid: El Viejo Topo.

Melero, N. (2012). Evolución de la política social y de descentralización en cuba: participación y desarrollo a nivel comunitario. Entelequia: revista interdisciplinar, 14, 19-31.

Melero, N. (2011). La participación de la mujer en el acceso y la gestión del agua: una experiencia cubana. Revista Andaluza de Ciencias Sociales, 10, 21-30.

Miles, M. B., Huberman, A. M., \& Saldana, J. (2014). Qualitative data analysis. USA: Sage Publications.

Moreno, A. (2013). La Cultura como Agente de Cambio Social en el Desarrollo Comunitario. Arte, Individuo y Sociedad, 25(1), 69-84. doi:10.5209/rev_ARIS.2013.v25.n1.41166

Palou, J., Rodríguez, M., \& Vila, R. (2013). Convivencia y participación de jóvenes en Sant Boi de Llobregat (Barcelona). Revista de Educación, 361, 252-278. doi: 10-4438/1988-592X-RE-2011-361-142

Park, P. (1992). ¿Qué es la Investigación participativa?: Perspectivas teóricas y metodológicas. En M. E. Salazar (Ed.), La Investigación Acción Participativa: Inicios y desarrollos (pp. 135-147). Madrid: Popular O.E.I.

Pérez, G. (1998). Investigación cualitativa: Retos e interrogantes (Vol. 1) Madrid: La Muralla.

Quintana, A. (2006). Metodología de Investigación Científica Cualitativa Psicología. Tópicos de Actualidad. Lima: UNMSM.

Ramírez, L. A. (2007). Mujeres del agua: desarrollo, participación y corresponsabilidad de la mujer como ejercicio cotidiano. Revista venezolana de estudios de la mujer, 12 (29), 63-90.

Rodríguez Villasante, T., Montañez, M., \& Martí, J. (2002). La investigación social participativa: Construyendo ciudadanía (Vol. 1) Madrid: El Viejo Topo.

Rojas, B. (2010). Investigación Cualitativa. Fundamentos y Praxis. Caracas: Fedeupel.

Sallah, M. (2014). Participatory action research with "minority communities" and the complexities of emancipatory tensions: intersectionality and cultural affinity. Research comparative and international education, 9 (4), 402-411. doi:10.2304/rcie.2014.9.4.4O2

Sepulveda, M.P., Calderón, I., Ruíz, C., \& Beltrán, R. (2008). La investigación acción participativa: una estrategia de formación para transformar la realidad en un Centro de reforma juvenil. Investigación en la escuela, 101-112.

[ 226 ] NOELIA MELERO AGUILAR, REINA FLEITAS RUÍZ

SIPS - PEDAGOGIA SOCIAL. REVISTA INTERUNIVERSITARIA [1139-1723 (2015) 26, 203-228] TERCERA ÉPOCA 
Sepulveda, M. P., Calderón, I., \& Torres, F. J. (2012). De lo individual a lo estructural. La investigación-acción participativa como estrategia educativa para la transformación personal y social en un centro de intervención con menores infractores. Revista de Educación, 359, 456-480. doi: 10-4438/1988-592X-RE-2010359-102

Taylor, S., \& Bogdan, R. (2000). Introducción a los métodos cualitativos de investigación. México: Paidós.

Tekin, A. K., \& Kotaman, H. (2013). The Epistemological Perspectives on Action Research. Journal of Educational and Social Research, 3(1), 81-91. doi: 10.5901/jesr.2013.v3n1p81

Vargas, G., Varela, L., \& Aparicio, P. (Diciembre 2014). Aproximación educativa y social a la acción comunitaria en España y Alemania. Revista de Educación Social, 19. Retrieved from http: www.eduso.net/res

Wilson, V., Ho, A., \& Walsh, R. (2007). Participatory action research and action learning: changing clinical practice in nursing handover and communication. Journal of Children's and Young People's Nursing, 1 (2), 8592.

\section{Notas}

${ }^{1}$ La Investigación forma parte del Proyecto "Formación de actores locales, en metodologías de participación comunitaria con perspectiva de género, para la solución de problemas de acceso y saneamiento de agua en el barrio de Jesús María. Municipio Habana Vieja. Cuba" realizado en 2010-2011. Financiado por el Ministerio de Asuntos Exteriores y de Cooperación. Agencia Española de Cooperación Internacional para el Desarrollo (AECID) en el marco del Programa de Cooperación Interuniversitaria e Investigación Científica (PCI). Resolución (A/O27761/O9) implementado en 2010. Resolución (A/O33373/10) implementado en 2011.

2 “Talleres de Transformación Integral de Barrio" (TTIB) surgen a partir de los noventa, a raíz de la crisis económica que azotó la economía cubana, están formados por equipos de trabajo multidisciplinarios que trabajan en torno a temáticas como el mejoramiento de las condiciones de la vivienda, la educación urbana de niños y jóvenes, la identidad comunitaria, el desarrollo de la economía local o la prevención social.

3 Unidad territorial más pequeña que el Consejo Popular o Barrio.

4 Camiones cisternas

5 The research is part of the project titled "Educating local figures in community participation methodologies with gender perspectives to solve problems regarding access to water and sanitation in the Jesus Maria neighborhood. Municipality of Old Havana, Cuba" which was carried out in 2010 - 2011 and was financed by the Ministry of Foreign Affairs and Cooperation, the Spanish Agency for International Development Cooperation (AECID, in Spanish) as part of the Inter university and Scientific Research Cooperation Program ( $\mathrm{PCl}$, in Spanish). Resolution (A/O27761/O9) implemented in 2010. Resolution (A/O33373/10) implemented in 2011.

${ }^{6}$ Integral Transformatin workshops in neighborhoods (TTIB, in Spanish) started in the 90's as a result of the economic crisis that hit Cuba. The workshops are made up by multidisciplinary teams that work on issues such as the improvement of housing conditions, urban education for children and adolescents, community identity, the development of the local economy, and social prevention.

7 Unidad territorial más pequeña que el Consejo Popular o Barrio.

8 Cisterntrucks

\section{CÓMO CITAR ESTE ARTÍCULO / HOW TO CITE THE ARTICLE}

Melero Aguilar, N., \& Fleitas Ruiz, R. (2015). La investigación acción participativa en procesos de desarrollo comunitario: una experiencia de cooperación interuniversitaria en el barrio de Jesús María, La Habana Vieja (Cuba). Pedagogía Social. Revista Interuniversitaria, 26 203-228. DOI:10.7179/PSRI_2015.26.08

Fecha de recepción del artículo / received date: 07.IV.2014

Fecha de revisión del artículo / reviewed date: 21.IV.2014

Fecha de aceptación final / accepted date: 12.II.2015 


\section{DIRECCIÓN DEL AUTOR/AUTHOR' ADDRESSES}

Noelia Melero Aguilar. Dpto. Teoría e Historia de la Educación y Pedagogía Social. Facultad de Ciencias de la Educación. Universidad de Sevilla. C/Pirotecnia, s/n. 41013. Sevilla (España).

Reina Fleitas Ruiz. Cátedra UNESCO de Desarrollo Humano y Sostenible. Dpto. de Sociología. Colina Universitaria. Calle San Lázaro y L. El Vedado. Ciudad de La Habana (Cuba).

Correo electrónico/e-mail: nmelero@us.es, rfleitas@ffh.uh.cu

\section{PERFIL ACADÉMICO/ACADEMIC PROFILE}

Noelia Melero Aguilar. Doctora en Pedagogía. Profesora del Dpto. de Teoría e Historia de la Educación y Pedagogía Social, de la Facultad de Ciencias de la Educación de la Universidad de Sevilla. Es miembro del Grupo de Investigación: "Educación de personas adultas y desarrollo" de la Universidad de Sevilla y sus líneas principales de investigación se centran en la educación social y comunitaria, las metodologías participativas de investigación y la cooperación internacional para el desarrollo. Cuenta con numerosas publicaciones sobre la pedagogía social y la educación comunitaria. Ha sido docente y miembro de la Comisión académica y de coordinación en diversos Máster y Expertos universitarios. Ha participado en diferentes proyectos financiados por la AACID y la AECID, y colabora estrechamente con la Universidad de la Habana, la Universidad Abdelmalek-Essaadi de Tánger, y FLACSO-Argentina.

Reina Fleitas Ruíz. Doctora en Sociología. Profesora Titular del Departamento de Sociología. Facultad de Filosofía e Historia de la Universidad de la Habana. Miembro de la Cátedra Internacional UNESCO de Desarrollo Humano Sostenible de la Universidad de La Habana. Máster en Sociología. Máster en Estudios sociales aplicados. Universidad de Zaragoza, España. Coordinadora y Docente de diversos diplomados universitarios sobre desarrollo humano, organizados con el Programa de Desarrollo Humano Local, de Naciones Unidas en Cuba. Sus principales líneas de investigación se centran en temáticas de género y salud, desarrollo humano, cooperación internacional y trabajo social comunitario, realizando diversas investigaciones y publicaciones con la Cátedra de la Mujer de la Universidad de La Habana y con distintas agencias de Naciones Unidas en Cuba; UNIFEM, UNICEF, OPS, UNFPA, PDHL/PNUD.

[ 228 ] NOELIA MELERO AGUILAR, REINA FLEITAS RUÍZ 